\title{
Marketing Efficiency and Marketing Channel Choice assessment of Manggo Fruit
}

\author{
Syahrul Ganda Sukmaya ${ }^{1, *}$, Ulpah Jakiyah ${ }^{1}$ \\ ${ }^{1}$ Universitas Perjuangan Tasikmalaya, Departement of Agribusiness, Tasikmalaya 46115, Indonesia
}

\begin{abstract}
This study aims at evaluating the marketing effectiveness and added value of mangoes in Majalengka Regency using: (a) describe the marketing channels, (b) marketing function, and (c) to analyze the marketing efficiency. Based on research findings, there are five marketing channels in Majalengka Regency's mango marketing channels. Based on the analysis and research conducted, it was found that there are five marketing channels found in mango marketing in Majalengka Regency. The added value in mango marketing today is mostly done by traders and the processing industry, while the provision of added value by farmers is still few. The overall added value in mango marketing in Majalengka regency is linked to the development of the mango sponge processed industry, but the scale is still limited. Therefore, there needs to be increased effort and support for entrepreneurs engaged in the mango processed industry. Lastly, of the five marketing channels that are on mango products, two marketing channels are most efficient compared to other marketing channels.
\end{abstract}

\section{Introduction}

The market access to farmers is an integral part of market involvement. Smallholder farmers can enter the market by selling products at the farm gate or moving products to the market using available means. Several researchers have researched market access generators. For example, [1, $2,3]$, Find those good roads, having a contract with buyers, and access to information have had a positive effect on farmers' market access because of their impact on transaction costs reduction. Nevertheless, the key obstacles to smallholder access to lucrative markets are the quantities sold, low quality of the goods that were sold, and lack of knowledge on the market [4].

[5] clarified the problem of market access by arguing that high-value crops that are frequently to be lost are generally linked to high transaction costs, high transportation costs, and inadequate cold chain facilities, restricting the access of smallholders to markets. The authors alert, however, that reaching these markets requires a major quality, quantity, and management upgrade of the product. $[6,7]$ also have findings that support the idea that farmers' ability to successfully access and participate in Agricultural production markets are linked strongly with basic agricultural inputs and key agricultural properties.

As a result of rising public income, the market demand for fruit commodities has increased. Higher incomes inspire people to pursue healthy lifestyles through fruit intake.

\footnotetext{
*Corresponding author: syahrulganda@gmail.com
} 
Mangoes are one of the fruit commodities that customers desire. There are different types of mangoes on the market, and each type can attract consumers to eat them. The supply of mangoes to consumers is mainly filled by manufacturers in many areas of the center of mango production. Mango business growth has a promising potential because there is still a significant demand for the business. Mango fruit market demand isn't just the domestic market, but export demand is still available. There are a variety of barriers to the growth of the mango industry.

Popular problems in the field of mango production centers include supply sustainability, the characteristics of different products, and the production quantity which could not meet demand on the market. In addition, the poor capacity of actors to exploit market opportunities is a concern for the production of mango commodities [8]. Small commodity value-added makes manufacturers especially susceptible to price shocks. When harvested, mangoes can exceed IDR 5,000/kg, often lower, at the producer level. The most vulnerable are producers because receipts can not cover manufacturing costs. If this continues, production will decline because the production of mangoes is not incentivized.

The demand for agricultural commodities defines the number of agricultural commodities that can be pushed through the marketing mechanism and become a standard for producers in the development phase [9]. An analysis of demand success is, therefore, required in order to know how many players in the Mango marketing system are motivated. This means that the stronger the demand for agricultural goods, the larger the number of participants in the marketing sector. The definition of the supply chain is the mechanism by which all the manufacturing, delivery, and marketing operations of the commodity may be carried out in compliance with the desires of customers and suppliers with the correct amount, cost, time, and place of the commodity [10]. In contrast, the value chain is the whole operation that creates a "chain" between the producer and the customer, where the added benefit of the commodity happens in each operation "link" before the final user absorbs the commodity [11]. On this basis, it can be inferred that the idea of a supply chain and value chain is an idea that complements each other.

\section{Methodology}

The research method to be used is to use a functional approach to see the added value of the product and marketing efficiency. Linked functio nal efficiencies of marketing execution that can boost or optimize the production ratio of marketing inputs [12]. The methodology used is the methodology of the marketing profit and the share of the farmer.

\subsection{The Functional Approach}

A function approach is an approach to marketing studies of business activities that occur or treatment that exists in processes in the marketing system that will improve and or create value in order to meet the needs of consumers (satisfaction). There are three important characteristics in the approach of marketing functions [13]. First, the impact of the implementation of the function is not only on the cost of marketing but also the value of the product to consumers. Processing, storage, and transportation will increase or create value for shape, space, and time for consumers. Second, there is a possibility of reducing or eliminate the middleman, but it is not possible to eliminate marketing functions. Third, marketing functions can be performed by anyone (company, individual, or group) aimed at various stages or places in the marketing system and increase or create value for agricultural products. The approach of marketing functions consists of 3 types, namely exchange functions, physical functions, and facility functions [13-15]. The marketing functions can be seen in figure 1 . 


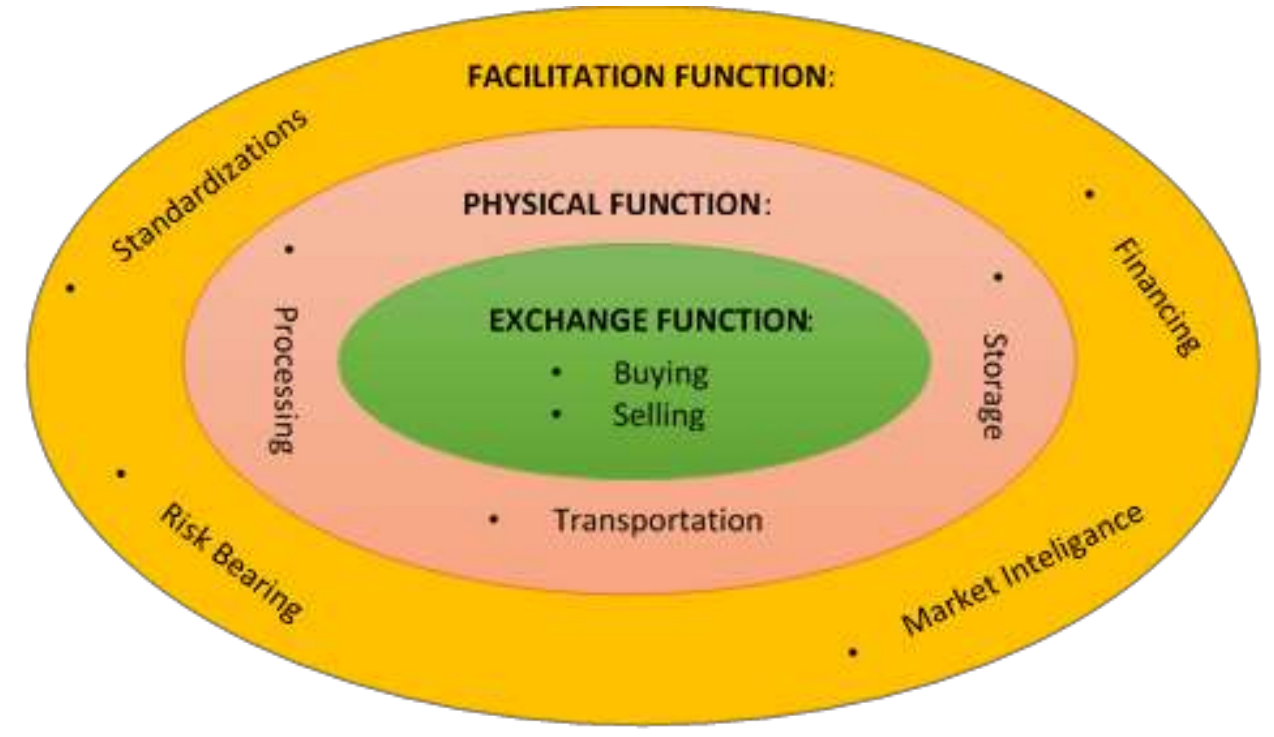

Fig 1. Marketing Functions

Source: [13]

\subsection{Marketing margin analysis}

Margin marketing is used to evaluate the distribution mechanism from a macro viewpoint, i.e., to examine the selling of goods varying from consumer producers to end-users. From the microperceptive of such businesses, the marketing margin is the discrepancy between the sales price and the marketing margin and the expense and benefit of the firm related to the commercial operations carried out by the organization [12]. Caution is required when reading marketing margins. Increased marketing profits, however, a great deal of care (functions) existed, and customers were pleased with the finished product, showing the propensity of the commodity marketing mechanism to be effective. Mathematically, the formula used to calculate the marketing margin is:

$$
\begin{aligned}
& T M=P_{r}-P_{f}=C+\pi \text { Institution }=\sum M_{\mathrm{i}} \\
& M_{\mathrm{i}}=P_{\mathrm{i}}-P_{\mathrm{bi}}
\end{aligned}
$$

\begin{tabular}{|c|c|}
\hline TM & $=$ Total margin \\
\hline $\operatorname{Pr}$ & $=$ Mango Price in retail (end level costumer) \\
\hline Pf & $=$ Mango Price at farmer's \\
\hline $\mathrm{C}$ & $=$ Marketing cost at mango \\
\hline$\pi$ Institution & $=$ Profit in marketing institution at marketing channels \\
\hline Mi & $=$ Margin at " $\mathrm{i}$ " mango marketing level, where "i" $=1,2, \ldots, n$ \\
\hline ij & $=$ Selling price of mango at marketing level in "i" \\
\hline $\mathrm{i}$ & $=$ Buying price of mango at marketing level in "i" \\
\hline
\end{tabular}

Where as in this chase: 


\subsection{Farmer's Share Analysis}

Farmer's contribution is part of the amount charged by the end-user in percentage terms to producers. The degree of manufacturing, freight cost, commodity longevity, costs of freight, and the number of goods affect the sum of farmers' share [13]. The larger the farmer's percentage, the greater the price the farmers get. The method used to measure the share of farmers is:

$$
F^{v} s=\left\{\frac{P_{f}}{P_{\pi}}\right\} x 100 \%
$$

Where as in this case:

F's = Farmer's Share

$\operatorname{Pr} \quad=$ Mango price in retail (end level costumer)

Pf $\quad=$ Mango Price at farmer's

\section{Result and Report}

\subsection{Value-added and marketing channels of mango fruits}

Figure 2 shows the results of research in the form of channels, functions, and added value marketing mangoes in Majalengka Regency. The results of the analysis showed that there are five marketing channels contained in mango marketing. Marketing agencies involved in mango marketing channels are merchant middlemen (small assembler at village level), merchant middlemen (wholesalers), and retailers both inside and outside the city. The first mango marketing flow is mangoes sold by farmers, then sold to wholesalers, then sold to retailers, and finally into the end consumer's hands. While on the second marketing channel, mangoes are sold by farmers to merchant middlemen (small assembler at village level) to be then sold to the manufacturers (cake and bakery industry) than to end consumer. The third marketing channel, mangoes are sold by farmers merchant middlemen (small assembler at village level), then sold to wholesalers then sold to retailers and lastly sold to the end consumer. The fourth marketing channel is mangoes sold by farmers to merchant middlemen (small assembler at village level) and then to wholesalers and sold to the final consumer. Finally, the fifth marketing channel is mangoes are sold by farmers to merchant middlemen (small assembler at village level) than to end consumer.

Marketing functions performed by mango marketing institutions are exchange functions, physical functions, and facility functions. Most marketing functions are performed by merchant middlemen (wholesalers). Marketing activities carried out by merchant middlemen (wholesalers) include purchasing, selling, distributing goods, storage, capital to farmers, processing, and standardization of products (sorting and grading). The role of merchant middlemen (wholesalers) is very involved in mango marketing channels in majalengka regency. The position is demonstrated by many marketing functions performed by merchant middlemen. 


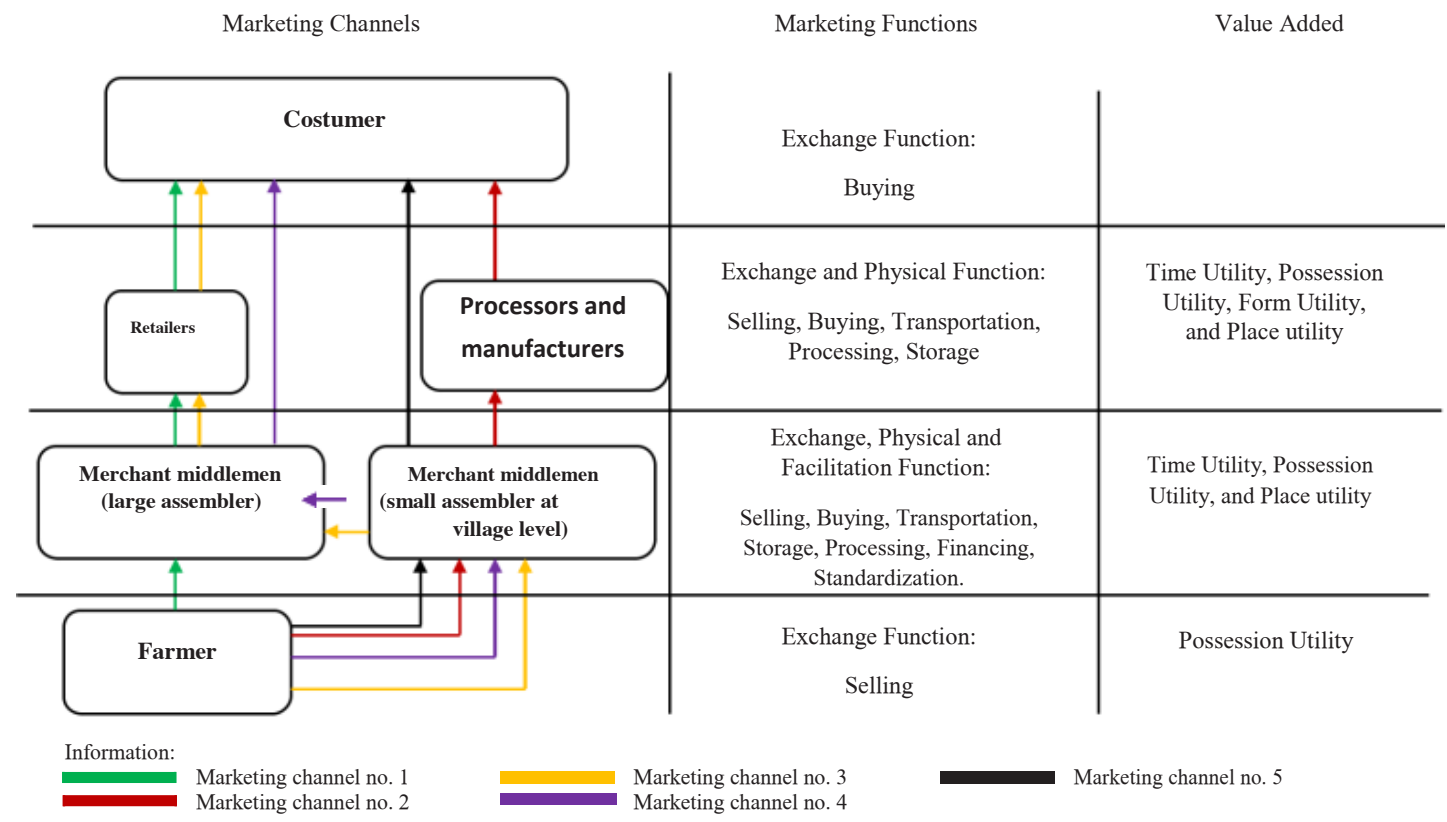

Fig 2. Marketing channels, functions, and value-added of mango 
Merchant middlemen carry out the distribution of goods by taking mango crops to farmers. Besides, merchant middlemen (wholesalers) provide capital for farmers in agricultural inputs (such as fertilizers and medicines). The merchant middlemen carry out processing mango fruit in the form of giving a layer of wax before the fruit is sent to the retailer, the purpose so that the fruit is durable and not easily damaged. In merchant middlemen also carried out storage activities. The purchased fruit is then collected in the storage warehouse before sorting and grading to be sent to local and out-of-town retailers. Finally, the merchant middlemen (wholesalers) performs the sorting and grading process. Sorting is done by sorting the fruits that are still good, judging by the level of maturity. While grading is done based on the type and size of fruit obtained from farmers, large fruit $(0.16$ to 0.25 grams per piece) and its smooth appearance is included in category A, while the size of the fruit is small ( 0.14 to 0.125 grams per piece) and the impression is quite good into grade B category. In contrast, the fruit that does not fall into that category includes grade $\mathrm{C}$ or nongrade. The standardization of goods is customized to the desires of merchants and the customers they represent. Retailers' marketing practices cover the delivery of products, transactions, acquisitions, and storage.

The added value done by mango marketing agencies can be said to be few. Product value-added is currently limited to the process of flowing products from primary manufacturers to end consumers. The high value-added in the form of processing process into mango derivative material is still very limited. Currently, there is a mango processing industry into a steamed sponge mango. However, now, the mango steamed sponge processing business scale is still limited and needs to be redeveloped.

The most considerable mango added value is in marketing institutions such as collectors, retail, and processing industries. The added value provided by the collecting trader is the value-added ownership, the value-added time, and the added value of the place. In retailers, the added value of the given product is the value-added ownership, the valueadded time, and the added value of the place. Lastly, industry processing's marketing institution provides value-added form; value-added ownership, value-added place, and value-added time.

\subsection{Marketing margin and farmer's share analysis of mango}

Marketing margin analysis tool and farmer's share is used to know the operational efficiency of mango marketing in Majalengka Regency. In the previous analysis related to mango marketing channels, there were five marketing channels for mango products. Each marketing channel will be analyzed using a marketing margin analysis and the farmer's share. These results will be obtained as the best alternative option for farmers in choosing the most profitable marketing channel. Besides, for policymakers, it can be used to measure marketing efficiency based on marketing margins, farmer's share, and marketing functions performed by marketing agencies.

The results of the study in table 1 show that the highest marketing margin sits at the no. 2 marketing channel, and the lowest is on the no. 1 marketing channel with a marketing margin value of IDR 35,000 and IDR 10,000 respectively. Meanwhile, the highest farmer's share value is at the no. 1 marketing channel and the lowest on the marketing channel no. 2 . Based on marketing margin analysis and farmer's share shows that marketing channel 1 is arguably the most efficient compared to other marketing channels, which are 2,3,4, and 5 . However, it is worth noting that marketing activities are carried out on that marketing channel. 
Based on marketing activities conducted by marketing agencies 1 and 2, the added value provided by marketing agencies 2 is higher compared to marketing agencies 1 . This can be seen from the marketing functions performed by both marketing agencies. In marketing institution 2 is done the value-added form where there is a process of processing mangoes into derivative products that have a higher value. In addition, it can also be seen based on the selling price at the consumer level. The selling price at the consumer level on marketing channel 2 is higher due to the very high value-added process. Based on this, it can be said that 2 marketing channels are most efficient compared to other marketing channels. Although the marketing chain is long, the marketing margin is high, and the farmer's share is low, but the value-added product is very high compared to other marketing channels.

Table 1. Marketing margin and farmer's share of mango in Majalengka District

\begin{tabular}{|c|l|c|c|c|c|}
\hline No. & $\begin{array}{c}\text { Marketing } \\
\text { channel }\end{array}$ & Farmer Price & Retail Price & $\begin{array}{c}\text { Total value of } \\
\text { Marketing } \\
\text { Margin }\end{array}$ & $\begin{array}{c}\text { Farmer's share } \\
\text { value }\end{array}$ \\
\hline 1 & Marketing channel 1 & IDR 13,000 & IDR 23,000 & IDR 10,000 & 56.52 \\
\hline 2 & Marketing channel 2 & IDR 10,000 & IDR 45,000 & IDR 35,000 & 22.22 \\
\hline 3 & Marketing channel 3 & IDR 10,000 & IDR 23,000 & IDR 13,000 & 43.48 \\
\hline 4 & Marketing channel 4 & IDR 10,000 & IDR 23,000 & IDR 13,000 & 43.48 \\
\hline 5 & Marketing channel 5 & IDR 10,000 & IDR 23,000 & IDR 13,000 & 43.48 \\
\hline
\end{tabular}

\section{Conclusions}

Based on the analysis and research conducted, it was found that there are five marketing channels found in mango marketing in Majalengka Regency. The added value in mango marketing today is mostly done by traders and the processing industry, while the provision of added value by farmers is still few. The overall added value in mango marketing in Majalengka regency is linked to the development of the mango sponge processed industry, but the scale is still limited. Therefore, there needs to be increased effort and support for entrepreneurs engaged in the mango processed industry. Lastly, of the five marketing channels that are on mango products, 2 marketing channels are most efficient compared to other marketing channels.

Acknowledgment. This research is part of my research entitled "Supply Chain and Mango Fruit Added Value," which was funded by the Ministry of Research and Technology on the competitive grant research scheme DPRM-PDP DIKTI in 2020.

\section{References}

1. M. Kumar, B Ganesh and Datta, KK and Reddy, G and Menon, Agric. Econ. Res. Rev. 23, 105 (2010).

2. Ruijs, C. Schweigman, and C. Lutz, in Agric. Econ. (No longer published by Elsevier, 2004), pp. 219-228.

3. H. Kyomugisha, C. Sebatta, and J. Mugisha, Sci. African 1, e00013 (2018).

4. M. Johnson, P. Hazell, and A. Gulati, Am. J. Agric. Econ. 85, 1211 (2003).

5. P. Pingali, Y. Khwaja, and M. Meijer, Commercializing Small Farms: Reducing Transaction Costs (2005).

6. Zezza, P. Winters, B. Davis, G. Carletto, K. Covarrubias, L. Tasciotti, and E. Quĩones, Eur. J. Dev. Res. 23, 569 (2011). 
7. E. Katungi, D. Karanja, D. Wozemba, T. Mutuoki, J.C. Rubyogo. A cost-benefit analysis of farmer-based seed production for common bean in Kenya. Afr. Crop Sci. J. 19 (4) (2011) 409-415.

8. R. Sulistyowati, Lies and Natawidjaja, Ijaber 11, 7537 (2016).

9. Saliem HP, editor Tinjauan konseptual makro-mikro pemasaran dan implikasinya bagi pembangunan pertanian. Forum Penelitian Agro Ekonomi; 2016.

10. Marimin DT, Suharjito HS, Utama D, Astuti R, Martini S. Teknik dan analisis pengambilan keputusan fuzzy dalam manajemen rantai pasok. Bogor: Percetakan IPB. 2013.

11. Kusumawardani MH. Membuat rantai nilai lebih, berpihak pada kaum miskin: buku pegangan bagi praktisi analisis rantai nilai: Australian Centre for International Agricultural Research (ACIAR); 2012.

12. Asmarantaka, R.W. (2012). Pemasaran Agribisnis (Agrimarketing). Bogor: Departemen Agribisnis. Fakultas Ekonomi Manajemen. Institut Pertanian Bogor.

13. Kohls, R.I., J.N Uhl (2002). Marketing of Agricultural Products. Ninth Edition. New Jersey: Prentice-Hall.

14. Dahl DC and Hammond JW. 1977. Market and Price Analysis. The Agricultural Industries. McGraw-Hill, Inc. Printed in the USA.

15. Schaffner DJ, Schroder WR, and Earle MD. 1998. Food Marketing, An International Perspective. Malaysia: WBC/McGraw-Hill. ISBN 0-07-116722-6.Printed. 